\title{
木本與草本植物間嫁接教飨試驗的 初步試驗結果
}

沈 德 粕

\section{（浙汇大學園藝系）}

通常一年生的草本植物和多年生的木本植物 之間，在組織方面有草質经和木質萨的不同; 在生 理方面有原形質間的區別, 這些因素都足以引起 生長習性上的差異。因此, 在嫁接方面常造成兩者 接口不容易澺合, 或者雖能暫時的瘜合而以後不 能恢復正常生長的現象。䍿焉的試驗目的, 除了 希望登望木本和草本植物間榢接成活的可能性以 外, 更茠望㢈用於育種方面而進行無性雜交(嫁 接教青處理)。在方法上是這樣的: 當兩者接活以 後, 將接悡(作第被教養者)的葉片,除了經常保留 先端二、三枚外，其食的都絡續摘去; 將砧木(作第 教餋者)的渠片，盡可能保留，使接穗生長開花和 結實所须的䓹分, 大多由砧木供給, 使得引起影響 和改造作用，接想有可能偭向於砧木特性的改變。

一般嫁接教養試驗中，被教素者在生長發有 程序上，常都滥先選取自己慗造的養液，教養者所 供給的常有程度上的不合適的。被教食者可以根 本不能问化而政死亡的，或者僅同化那些適合其 浀求的物質，然而在分量上往往是不够充裕的，所 以生長發育會受到抑制, 甚至不能開花結果。這啐 更由於木本與草本植物間的嫁接，在養分的瓝給 上保在了某些原因上的困難, 更因点去装教養的 絣故, 所以嫁接成活的百分率顯然更低了。但是在

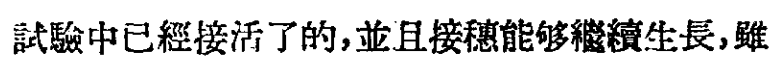
然是很緩慢地却同樣能喽開花和結實。這說明了

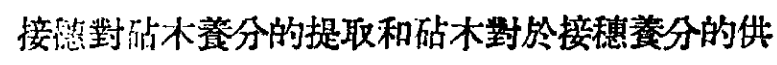
給，在木本和草本植物閏的嫁接上是相賞的困嚾， 而在在些植物種類上是可以管現的。因此,進一步 希撉草本的截唔植物, 能够從嫁接教䓹中獲得它 所需要而木本植物所具有的传良特性, 以篔强它

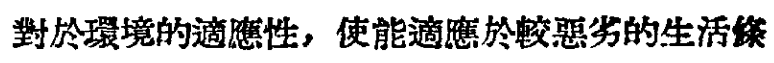
件下，而得到合乎裁培者所希望的新的植物程類 的育霆上成就。

\section{試龭綵過及結果}

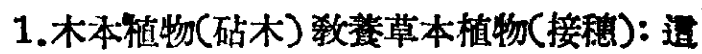
是番茄和构杞間的嫁接数莶試驗, 以枸杞窟砧木 数養接䄸番茄(圖一)。番茄在杭州莱候绦件下是一

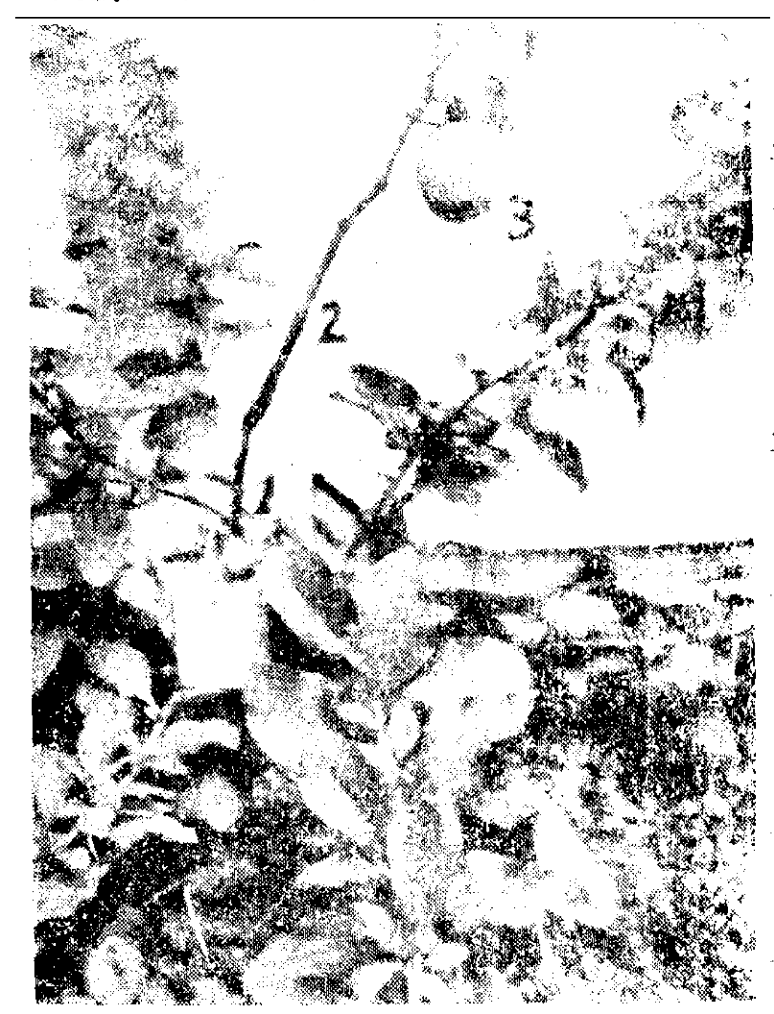
圆一 番茄+构杈
1. 砧木构杞
2. 接䍐番茄
3. 番茄果子

年生的草本植物，在無霜的季節裹可以生畏，遇箱 
新要死亡，所以植株不能在露地越冬。构杞 ( $\mathrm{L}_{\mathrm{y}}$ eum òninensis L.) 在杭州是多年生的木本植物， 可以在霜地安全越冬,並且在田野間策茂存在,有

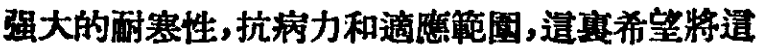

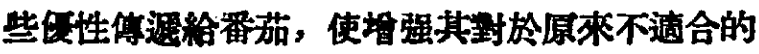
環境的抵抗能力。

荤試臨是在1950年進行的, 构杞在2月8日和 番茄在3月25日分別在温林內播種育苗, 在5月5日 行割接法嫁接。那時的砧木已相當長大，使自身遺

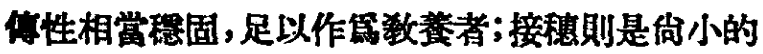

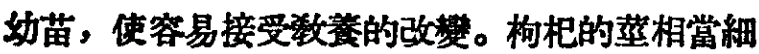
小，而且早期就木質化了，因此不僅在嫁接工作上 有困嚾，而且成活不容易，能够接活了的，接穗生

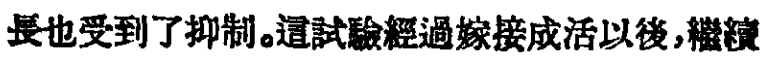
生長和能够結果的只一株，在近接口處的番茄接 穆的基部，有䫏著的跀大，同時密生了許多不定 根，遭可能是䓹分提取困難而峾求自力更生的表 徽。接穂除保留先端二、三枚外經賞去棐的, 策了 使新的生活佟件(砧木的食分)强迫它接受，除非 不能接受而死亡,否則，接穗的生舆開花結果所需 的巷分，大多是由砧木供給，而足以動播它原有的 生長習性,使促淮其随着砧木特性的改變。接穗生 長一分分緩慢，在第七節後形成花芽，道是頂芽變筬 花牙的, 所以此後不再伸長，㷛腋也汥有腋芽發

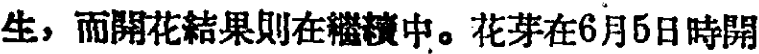
放，事先在蕾期時行套袋，防止有性雜交，以免影

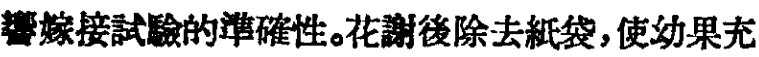
分肥大。在7月 2 日時結有横徑 2.5 厘米的兩個果 子。其中一個番茄倘未紅熟而在這時偶然磁下，重 11克,經過後等，到7月19日呈現橙紅色，眝藏期 相當長,遖到8月25日才切剖留種, 得到充富檑子 16粒。另一個番茄,在接穗上當8月1日時漸現橙糽. 色,到 8月13日已經紅熟, 8 月23日探取留檑, 果 重19.9克,得到種子26粒，其中有三粒.已經在果內 墢芽。

從敉養後的接穗的性狀看來，番茄的小染數 比教诚少而呈卵圆形,有像构杞葉形的,果子的梗 洼比较浅而小了，子室数變 少而篇二空的(原篇

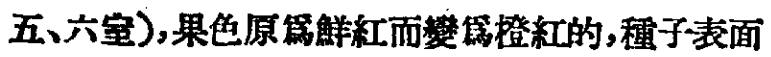

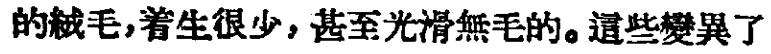
的現象, 可能是由於營盖佟件的不足所引起, 也許 是由於较美影繁的後果。
此外，特番荕嫁接於一株自田野掘取的多年 生构杞植株上，虽枸杷老袾在春天抽生做枝時行

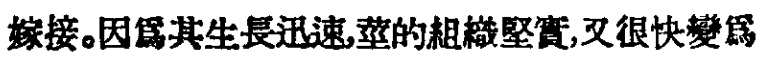
木質化，所以雨者接活而繼縇開花至於結果的只 有一株。接活後接䅹生長還块，接穗的節間比較原 來的細長,在第10和第20筐戱都曾經開花，但是汥 有結果，可能是由於氣候影響或是砧木供給接穗 的水分和食分不足的原故。到9月15日，在第28第 處又開花而結果, 在11月3日時, 還沒有成熟而掉 下，遖到11月15日才完成後熟作用，得到種子36粒。

2.草本植物(砧木) 较食木本植物(接穗): 通 是枸杞與辣椒間的嫁接教養試驗, 以䍶椒(一年生

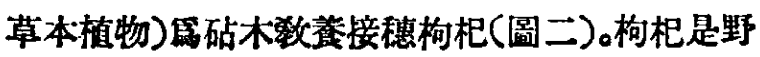

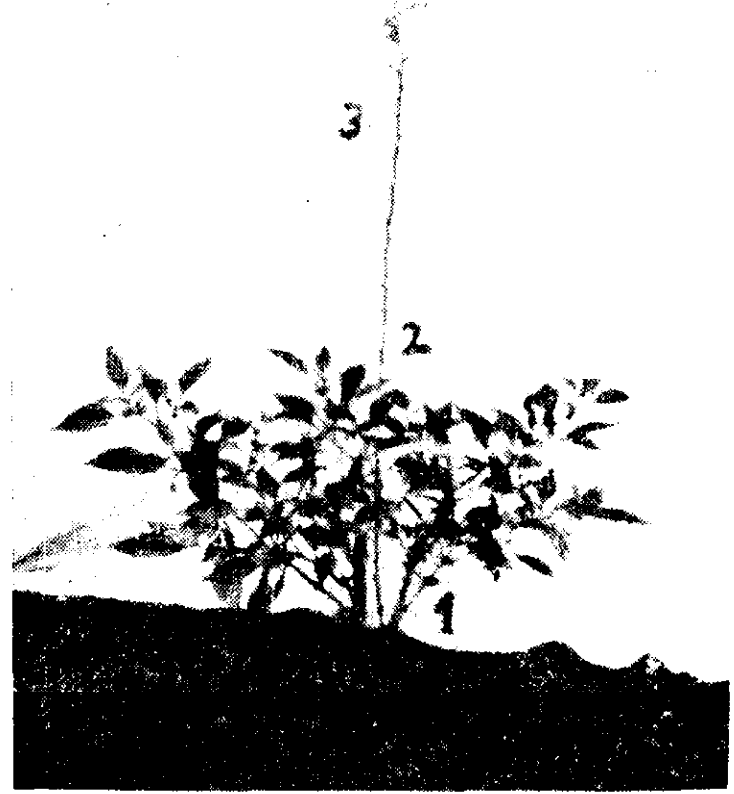

圆二枸祀十辣椒

1. 砧木辣椒

2. 接㫫构杞

3. 构杞果子

生植物,在自然間有較大的適應範園，長久生存繁

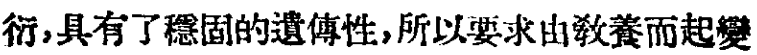
異是很困難的。道試媛以枸杞作第被数苓者，並不 是篇了有種實用上的目的, 而僅是第了草本與木 本植物間嫁接数䓹可能性的觀察和教食者對其有 無影響作用的望驗。

通試駿在1950年進行的。耞椒在 2 月 8 日和枸 杞在 3 月 25 日分别在温床內播種有苗, 在5月5日行 
割接法嫁接, 成活率很低, 也只有一株接活, 後來 踓桱去葉教桼, 接橞生長很䌅, 但也能開花結果

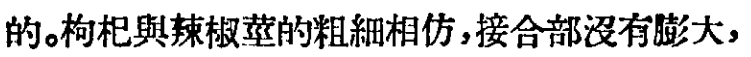
接穗的基部也涊有不定根發生, 除主枝外沒有新 枝抽生, 而渠片緜的小, 穊間較短。在 6 月 14 日 曾經開花, 但汥有結果 (其他未經 嫁接的枸杞植 株, 在那時也有同榡的現象), 到9月中下旬時先後 有花開放, 10 月底時果子成熟, 11 月初時探收留

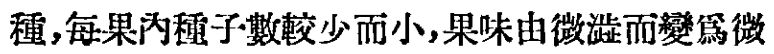
䍶, 果形由卵蒷而變䉆先端尖的了, 這些變巽現象 可能就是教食的影響。

\section{愔 論}

1.部分的多年 生木林植物與一年生 草本植 物; 估這試驗的例澄, 相互間可以接活, 並且可以 結果和得到種子, 踓然是經過去葉教養, 活着應該 更困難,但是可能的。

2.與本試驗相似的阔科異屬的睐椒與冬珊瑚 (Solanum pseudo-capsicumL.) 間的嫁接以後, 接 穗不見生長,也不调菱, 經過兩個月左右死亡。由
此看來, 本試驗還不能作一般性的推論, 還須要更 多的廣泛的試驗成果作第諭推後, 才可能得到結 論。

3.嫁接以後, 接橞往往不立刻调萎而活着相 賞時期, 沒有開花結果而死亡。這接橞暫時的生命 維持, 是否是由於接穗能够從砧木獲得水分的称 故? 這不能緂續生長是否是由於砧木所供給的苓 分不足或不適於接穗的需要之故?

4.測定嫁接教養俩性雜交的可能性, 僅在當 代被教養者(接穗或砧木)能够結果和得到種于以 及受到教養影響而有荣些變異, 不能說是, 與性社 交成功, 必須要獲得能够開花結賽的雜種子-代。所 以這無性雜交的成功與否要看下一代的情形才可 决定。

5.這次試驗嫁接成活的本數不多, 不能欲具 有一般的代表性, 但是本試驗中的事㝠, 木本與草 本植物間的嫁接(賞年), 在某些植物䄸類上是可 能的。所以淮一步希望使一年生草本植物敨蒵成 第多年生木本植物, 逼是本試驗的目的, 以後繼稀 工作再作報嶈。

\section{中國植物學會確定爲工農業建設服務的方針}

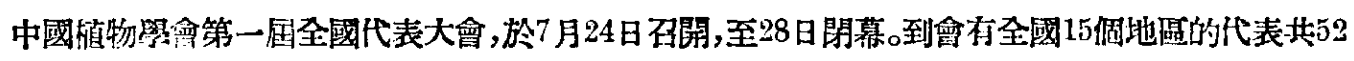

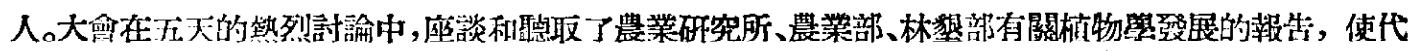

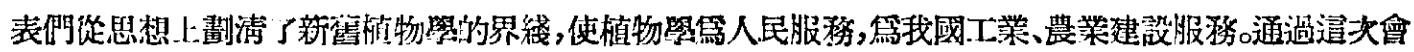

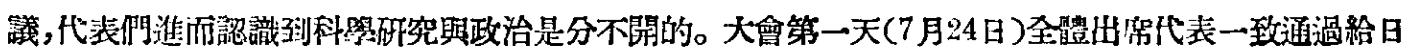
本植物科學工作者的一诗公開信。該信略程:中國人民和日本人民保衙世界和本的目眐是一致的，我們

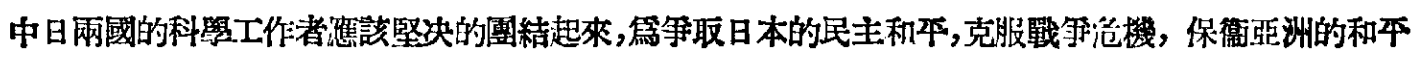
而窟閏。

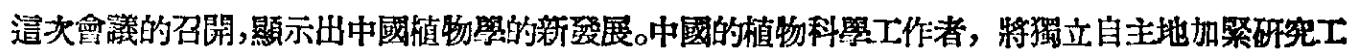
作,與全抴界愛好和平的民主國家值物科學工作者共同合作，爲人類光輝的交化而努力。

（人民日報 8月17日） 